University of Nebraska - Lincoln

DigitalCommons@University of Nebraska - Lincoln

Faculty Publications, Department of History

History, Department of

$12-27-2001$

\title{
MARTIN BUCER AND THE CHURCH FATHERS IN THE COLOGNE REFORMATION
}

Amy Nelson Burnett

University of Nebraska - Lincoln, aburnett1@unl.edu

Follow this and additional works at: https://digitalcommons.unl.edu/historyfacpub

Part of the History Commons

Burnett, Amy Nelson, "MARTIN BUCER AND THE CHURCH FATHERS IN THE COLOGNE REFORMATION" (2001). Faculty Publications, Department of History. 9.

https://digitalcommons.unl.edu/historyfacpub/9

This Article is brought to you for free and open access by the History, Department of at DigitalCommons@University of Nebraska - Lincoln. It has been accepted for inclusion in Faculty Publications, Department of History by an authorized administrator of DigitalCommons@University of Nebraska - Lincoln. 


\section{Martin Bucer and the Church Fathers in the Cologne Reformation}

\author{
Amy Nelson Burnett \\ aburnett1@unl.edu
}

\section{Abstract}

Martin Bucer's theology is perhaps the most difficult of all the major reformers to characterize because of its evolving nature. Although there are certainly fundamental features that remained constant through his career, what makes Bucer so unusual and so fascinating is the evolution of his thought as he worked out the implications of those fundamental beliefs and their specific applications over his years of experience as pastor, teacher and church organizer.

One of the areas in which Bucer changed over the course of his career was his use of the church fathers. Both Pierre Fraenkel and Robert Stupperich have pointed to a similar pattern in Bucer's citations from the church fathers and from canon law: a few references during the 1520s, growing frequency from about 1530, and significant use by the end of the 1530s. ${ }^{1}$ As an illustration of this general development, Irena Backus has emphasized the visible role Bucer gave the Fathers in his 1536 Romans commentary, a striking change from his tacit use of them in the three editions of his John commentary. ${ }^{2}$ Bucer's greater

1. Pierre Fraenkel, 'Introduction', Martini Buceri Opera Latina (Paris/Leiden: E.J. Brill, 1954-, henceforth BOL), 3, xviii; Robert Stupperich, 'Martin Bucer's Gebrauch des canonischen Rechts', in Marijn de Kroon and Marc Lienard (eds.), Horizons Européens de la Réforme en Alsace. Das Elsaß und die Reformation im Europea des 16. Jahrhunderts. Aufsätze zum 65. Geburtstag von Jean Rott (Société Savante d'Alsace et des Régions de l'Est, Collection 'grandes Publications', 17; Strasbourg: Istra, 1980), pp. 241-52.

2. 'Ulrich Zwingli, Martin Bucer and the Church Fathers', in Irena Backus (ed.), The Reception of the Church Fathers in the West From the Carolingians to the Maurists (Studies in the History of Christian Thought; Leiden: E.J. Brill, 1997), 2, pp. 627-60; see also Irena Backus, 'Martin Bucer and the Patristic Tradition', in Christian Krieger and Marc Lienhard (eds.), Martin Bucer and Sixteenth Century Europe. Actes du colloque de Strasbourg (28-31 août 1991) (Studies in Medieval and Reformation Thought, 52; Leiden: E.J. Brill, 1993), 1, pp. 55-69. willingness to cite the Fathers in defense of reform is evident already in his 1534 Defensio adversus Axioma Catholicum, as the recently published critical edition of this work makes clear. His involvement in imperial politics and the discussions with Catholic theologians associated with the religious colloquies, however, led to a new emphasis particularly on the institutions of the early church as a model for the reformed (small r) and catholic (small c) church. ${ }^{3}$ The Florilegium Patristicum that he began to assemble around this time contains excerpts from the Fathers that deal primarily with practical institutional issues such as church government, church discipline, and the proper ordering of ecclesiastical rites.

In comparison to work done on Bucer's early career, little attention has been paid to the role of the early church in Bucer's works from the 1540s. This would be a major undertaking, far beyond the scope of a single article. This paper will therefore examine one aspect of Bucer's use of the Fathers from this period by focusing attention on a major work from that decade, the Bestendige Verantwortung or Steadfast Defense of the Cologne reformation ordinance.

The Steadfast Defense cannot be separated from the circumstances in which it was written, as part of an extended debate with the Catholic theologian Johannes Gropper over the attempted reformation of Cologne. Both Bucer and Gropper had been key players in the religious colloquy of Worms in 1540 and had together produced the draft of the Regensburg Book which served as the basis for discussion during that religious colloquy in $1541 .{ }^{4}$ Bucer's involvement in these colloquies prompted the archbishop of Cologne, Hermann von Wied, to invite the Strasbourg reformer to assist when he decided to undertake a 'Christian Reformation' of his territory on his own initiative. ${ }^{5}$ The archbishop assumed that Bucer and Gropper would continue their partnership, but Gropper was adamantly opposed to Bucer's presence in the territory, and he quickly became the spokesman

3. Cornelis Augustijn, 'Bucer und die Religionsgespräche von 1540/41', in Martin Bucer and Sixteenth Century Europe, 2, pp. 671-80.

4. See the introduction to the 'Wormser Buch', Martin Bucers Deutsch Schriften (Gütersloh: Mohn, 1960-, henceforth BDS), 9/1, pp. 323-30, and the literature cited there.

5. On the Cologne Reformation, the most detailed account is still Conrad Varrentrop, Hermann von Wied und sein Reformationsversuch in Köln. Ein Beitrag zur detuschen Reformationsgeschichte (Leipzig: yon Duncker \& Humblot, 1878), supplemented by the discussion of Bucer's role, with related documents, in J.-V. Pollet, Martin Bucer, Etudes sur les relations de Bucer avec les Pays-Bas, l'Électorat de Cologne et l'Allemagne du Nord, avec de nombreux textes inédits (Studies in Medieval and Reformation Thought, 33-34; Leiden: E.J. Brill, 1985), 1, pp. 83-234 and 2, pp. 35-162; see also Marlin de Kroon, 'Bucer und die Kölner Reformation', in Martin Bucer and Sixteenth Century Europe, 2, pp. 493-506. 
for the Catholic opposition to the reformation attempt. The result was a propagandistic battle for the hearts and souls of the territory's inhabitants in which the writings of the Fathers and the traditions of the early church figured prominently. ${ }^{6}$

An echo of the role played by the Fathers at Cologne survives in Bucer's account of his ministry there, What is Now Being Taught and Preached in the Name of the Holy Gospel of our Lord Jesus Christ in Bonn. ${ }^{7}$ This pamphlet, which Bucer published in March, 1543, a few months after his arrival in the archiepiscopal territory, opened with a fifteen-point summary of his preaching and teaching. It began by describing the purpose and goal of preaching, moved on to repentance, rebirth, good works and the unity of the church, and concluded with issues of practice and ceremony: public worship, the sacraments, and the conduct of the clergy. Frequent marginal notations made clear to the reader the sources of Bucer's arguments.

The church Fathers do not appear in the first ten, most doctrinally-oriented points, which rely instead on frequent references to Scripture. Only Augustine is cited, once with regard to good works, and once as evidence that the Fathers themselves always submitted their teachings to Scripture. ${ }^{8}$ This pattern changed, however, as Bucer turned his attention to the sacraments and to the public rites and ceremonies of the church. While Scripture still dominated the marginal notations, patristic sources now appeared frequently as well. Bucer most intensive use of the Fathers occurred as part of his eleventh point, a discussion of the Lord's Supper. Under this heading, which comprised roughly one quarter of the section on his preaching, Bucer referred to Chrysostom five times, Cyprian three times, and Augustine twice. In addition, he cited canons contained in the Decretum three times, and he made five more unspecified references to the 'writings of 'the holy fathers', and spoke twice of early church practice, and once of the practices of the

6. I have been unable to consult the authoritative work by Theodor Schlüter, 'Die Publizistik um den Reformationsversuch des Kölner Erzbischofs Hermann yon Wied aus den Jahren 1542-47. Ein Beitrag zur rheinischen Reformationsgeschichte und -Bibliographie' (PhD dissertation, University of Bonn, 1957). Schlüter does, however, give a very brief overview of the polemics surrounding the reformation attempt in 'Der Streitschriftenkrieg um den Reformationsversuch in den Jahren 1543-1547', in Hans-Georg Link et al. (eds.), 450 Jahre Kölner Reformationsversuch: Zwischen Reform und Reformation (Alfter: Stallberg, 1993), pp. 83-88.

7. There is a mistake in the numbering of the points: the numbering is correct until point eleven (on the Lord's Supper), then repeats the numbers ten and eleven, moves to twelve, skips thirteen and concludes with fourteen.

8. BDS 11/1, pp. 37, 1.25-28; 38, 1.36-39 1.4
Greek church. ${ }^{9}$ Bucer clearly felt that the example of the early church was very important on this particular issue.

Although the Fathers do not occur so prominently in the remainder of the work, Bucer continued to cite them, both in the remaining four points summarizing his teachings and in his lengthy defense of his calling to Bonn. Again Chrysostom and Cyprian occurred with the greatest frequency, followed by Augustine and Jerome. Most frequent, however, are references to the provisions concerning church government incorporated into canon law. This might be expected, given that the issue of Bucer's calling was at heart a legal question. The Fathers disappeared again from the final, brief section of the pamphlet in which Bucer defended his Bonn ministry in general.

This brief overview of Bucer's preaching alerts us to the fact that the practices of the early church were an important component not so much of the doctrinal controversy, but in the debate over reforming ceremonies and practices in the archiepiscopal territory. As we shall see from a closer examination of the published debate between Bucer and Gropper, the Fathers were used by the Catholic side to oppose the 'innovations' introduced by the would-be reformers. This was a charge that Bucer would attempt to refute in his defense of the reformation ordinance written for the territory.

That ordinance, later published under Archbishop Hermann von Wied's name as A Simple Consideration Concerning the Establishment of a Christian Reformation, was primarily Bucer's work, although he was assisted in its composition by Philipp Melanchthon. ${ }^{10}$ The ordinance laid out the theological basis for reform in its opening sections and then dealt with practical institutional considerations such as the appointing and support of ministers, the conduct of public worship and other church ceremonies, and the administration of church discipline. The Simple Consideration was completed in July, 1543, and presented in manuscript form to a Diet of the territorial estates shortly thereafter.

Within a matter of weeks Johannes Gropper had responded with a critique of the Simple Consideration. When the reformation ordinance was published in February, 1544, the cathedral chapter quickly published Gropper's response under the title, $A$ Christian and Catholic Conjuration by the Hon-

9. BDS $11 / 1$, pp. $45-54$

10. The two reformers used various other church ordinances-most notably the Brandenburg-Nürnberg ordinance of 1533-as a model for the Cologne ordinance. For a detailed description of the composition and contents of the Simple Consideration, see Mechthild Köhn, Martin Bucers Entwurf einer Reformation des Erzstifts Köln. Untersuchung der Entstehungsgeschichte und der Theologie des 'Einfeltigen Bedenckens'von 1543 (Witten: Luther-Verlag, 1966). 
orable Cathedral Chapter of Cologne Against the Book of the so-called Reformation. ${ }^{11}$ Bucer had obtained a manuscript copy of Gropper's work shortly after its completion and began writing his own defense of the ordinance; as he wrote to Heinrich Bullinger in December of 1543, 'the Confutation is being confuted'. ${ }^{12}$ Bucer's response, A Steadfast Defense, drawn from Holy Scriptures and True Catholic Doctrine and Practice and the Deliberations of the Universal Christian Church Concerning a Christian Reformation, was published in early $1545 .^{13}$

Both the Confutation and the Steadfast Defense were very clearly focused on the provisions of the Simple Consideration. The Confutation proceeded through the reformation ordinance section by section, following a fixed pattern. Each section began with a statement of the position held by the universal church, supported by passages from Scripture, conciliar canons and the writings of the Fathers. Then, set off by a different typeface, Gropper described the provisions of the ordinance which contradicted the position of the universal church as he had described it. Finally, he criticized those provisions in light of Catholic doctrine and practice. As a further aid to the reader, the Confutation contained a chronological 'catalogue' of the ecumenical and national councils, as well as Fathers of both the eastern and western church, who were cited in the text. Only a handful of these lived after $600 \mathrm{AD}$, including two medieval theologians (Hugh of St. Victor and Bernard of Clairvaux) and three contemporaries or near contemporaries (Cardinal Bessarion, Beatus Rhenanus and Erasmus).

Although referred to in the preface as a 'short, Christian and steadfast defense', Bucer's response to the Confutation was in fact a thick folio of about 600 pages. In his typically long-winded and in this case pedantic fashion, Bucer turned Gropper's technique against him. The Steadfast Defense went through the Confutation section by section, first summarizing the criticisms of

11. Christliche und Catholische Gegenberichtung eyns Erwirdigen Dhomcapittels zu Cöllen wider das Buch der gnanter Reformation, so den stenden des Ertzstiffts Cöllen uff junxstem Landtage zu Bonn vorgehalten... (Cologne: Jaspar Gennep, 1544). That same year Gennep also published a Latin translation, Antididagma, seu christianae et catholicae religionis per.. Canonicos metropolitanae ecclesiae Coloniensis propugnatio, adversus librum quendam.. nuper Bonnae titulo Reformationis exhibitum... The Antididagma was reprinted in Louvain in 1544, in Venice in 1547, and in Paris in 1549.

12. Quoted in Max Lenz (ed.), Briefwechsel Landgraf Philipp's des Großmüthigen von Hessen mit Bucer, Zweiter Theil (Publikationen aus den königlichen preussischen Staatsarchiven, 28; Leipzig: Hirzel, 1887), p. 225 (Dec. 28, 1543).

13. A Latin translation, entitled Constans Defensio, ex s. scriptura, et vera catholica doctrina, atque observatione Vniversalis Christinae Ecclesiae Deliberationis de Christiana Reformatione...., was published in 1613 in Geneva and in 1618 in Basel. the ordinance in the Confutation, and then responding to every point, in many cases taking up each patristic citation used in the Confutation.

Both the Confutation and the Steadfast Defense are lengthy books, and it would be impossible to analyze their contents within the scope of this article. The debate on issues relating to the Mass/Lord's Supper alone takes up about a third of both the Confutation and the Steadfast Defense. Instead, I would like to examine the use of the church Fathers in these two works on three levels, moving from the more general considerations of the prefaces to each book, to the discussion of the relationship between Scripture and tradition in the first chapter, to an analysis of how Bucer used the writings of the Fathers in his defense of specific provisions of the reformation ordinance.

Both the Confutation and the Steadfast Defense were written with the inhabitants of the archiepiscopal territory in mind. The Confutation's goal was to demonstrate that 'the book of the so-called Reformation' deviated from the teachings and traditions of the universal church. In his preface to 'the Christian and Catholic reader', written in the name of the cathedral chapter of Cologne, Gropper employed two strategies. On the personal level, he maintained the polite fiction that the pious archbishop had been misled by the 'evil reports' of those who had written the ordinance 'according to their own ideas and judgment'. ${ }^{14}$ As a rhetorical counter-weight to these evil counsellors Gropper referred repeatedly to the 'Christian and Catholic' teachers and scholars who had examined the ordinance and had rejected it because of its many innovations.

This leads to Gropper's second, more general strategy: his oft-repeated charge that the ordinance was unacceptable because it introduced numerous innovations that opposed the universal tradition of the Catholic church. The cathedral chapter had protested against Bucer's very presence in the territory on the basis of 'God's word, the oldest canons of the Christian and Catholic councils and the holy Fathers', but their petitions to the archbishop had been ignored. Although they did not wish to seem to oppose the archbishop, the chapter was conscience-bound to publish its Confutation, because it feared that its silence would be interpreted as approval of the ordinance. The ordinance contained 'hidden poison' along with its 'many pretty words', and therefore the chapter felt compelled to explain to the territory's inhabitants those provisions that were opposed by 'Christian and Catholic doctrine and the common tradition of the church'. Gropper closed the preface with the fervent wish that the archbishop would realize that, 'although [the authors of the book] cry nothing but 'Scripture, Scripture', there are many, indeed countless

14. Gegenberichtung, a6r. 
new things that can be found neither in Scripture, nor in the oldest councils or in the holy Fathers, which they try to introduce according to their own judgment. And every Catholic should rightfully complain to the highest degree' ${ }^{15}$

In the preface to the Steadfast Defense, published in the name of the archbishop, Bucer responded to Gropper's preface point by point, in the process countering both the personal attack on the ordinance's authors and the general accusation of innovation. With regard to the character and orthodoxy of the two parties, Bucer pointed out that although his opponents called themselves God-fearing and Catholic, they opposed reform measures that were not only necessary, but that conformed to the canons of the early church. As evidence of their bad faith, Bucer charged that they had repeatedly refused invitations to meet with the committee appointed to go over the draft of the ordinance, something they would readily have done if they were indeed 'Christian, Catholic and God-fearing theologians and scholars'. ${ }^{16}$ It was an insult of the highest order to imply that the archbishop had been misled by evil people to introduce measures that opposed God's Word and true apostolic and Catholic tradition.

More importantly, however, Bucer maintained that the pious Christian reader should easily see that the ordinance "was in no way opposed to right, true Catholic tradition'. ${ }^{17}$ Indeed, the provisions of the ordinance were not innovations but rather 'the re-establishment of pious practices that are old, eternally true and right', what Christ and the apostles had established at the church's foundation. ${ }^{18}$ Bucer promised his readers that the body of the Steadfast Defense would clearly show that his opponents' charges of innovation were unfounded.

Bucer was given the opportunity to make good on this promise in the exchange over the first chapter of the reformation ordinance. The ordinance opened with a section 'on doctrine', based largely on the Brandenburg-Nürnberg ordinance of 1533, that made Scripture the basis of all teaching and preaching in the church. Pastors and preachers were to study God's word and to base their sermons on its contents and to use it in admonishing and correcting their parishioners as well as in refuting their opponents. ${ }^{19}$

\footnotetext{
15. Gegenberichtung, b1r-v.

16. Bestendige Verantwortung, $\mathrm{b} 3 \mathrm{v}$.

17. Bestendige Verantwortung, b5r-v.

18. Bestendige Verantwortung, b2r; b6r.

19. BDS 11/1, 170-79.
}

Gropper accordingly began his Confutation with a section 'on the doctrine of the Catholic church'. He stated that it was clear from the words of both the apostle Paul and the church fathers that the universal teachings of the Christian church were received partly in Scripture and partly through apostolic tradition passed down in private. Citing St. Basil, he argued that the written word and oral tradition were of equal weight in matters of salvation. ${ }^{20}$ As an example, he pointed out, the Apostles' Creed rested more on apostolic tradition than on Scripture. Irenaeus, Tertullian, Cyprian and a host of others also testified that the apostles did not put all their teachings in writing but left much unwritten. Canon law incorporated Augustine's words to the effect that the authority of Scripture and the authority of universal tradition were both binding on the church. Gropper accused the reformation ordinance of opposing these teachings in its specific statements that there was no reliable source of doctrine outside Scripture, and that Scripture itself was sufficient as the basis for doctrine. He also charged the ordinance with eliminating or making voluntary not only 'many Catholic actions and practices that were taught in the universal church from the time of the apostles' but also 'many specific salutary practices introduced in the archiepiscopal territory by the first bishops and pastors'. ${ }^{21}$

Bucer opened his response to this 'first accusation' of Gropper's with a general defense of Scripture as the basis of all doctrine. No other source could provide such certain testimony of God's will as did the contents of the Old and New Testament. In contrast, the Fathers themselves admitted that their books contained errors and did not agree on all things. Indeed, the Fathers based their writings on Scripture when they explained doctrine or wrote things that were useful for admonition, warning and consolation. The pious Christian

20. Basil was the first to postulate a two-source concept of tradition, and his statement on the importance of both Scripture and oral tradition was incorporated into the Decretum, which led to its adoption by canon lawyers. Medieval theologians were slower to accept the two-source theory of tradition, but this position became more clearly articulated over the course of the fourteenth and fifteenth centuries and was eventually adopted at the Council of Trent; Heiko A. Oberman, 'Quo Vadis, Petre? Tradition from Irenaeus to Humani Generis', in H.A. Oberman, The Dawn of the Reformation: Essays in Late Medieval and Early Reformation Thought (Edinburgh: T. \& T. Clark, 1986), pp. 269-96; Heiko A. Oberman, The Harvest of Medieval Theology: Gabriel Biel and late Medieval Nominalism (Cambridge: Harvard University Press, 1963), pp. 361-412. Gropper was a canon lawyer rather than a theologian by training, and his advocacy of the two-source understanding of tradition, as well as his reliance on canon law for the patristic citations to support that view, is therefore not surprising.

21. Gegenberichtung, 1r-rv. 
would therefore agree with the ordinance's statement that doctrine should be based solely on Scripture. ${ }^{22}$

Bucer then turned to the specific charges made by Gropper. As he repeatedly stated, his goal in this section was to demonstrate to his readers that the reformation ordinance contained nothing against genuine apostolic tradition. He began by conceding the existence and validity of oral traditions dating back to the apostles, as Scripture itself testified. The goal of these traditions, as Scripture made clear, was to help Christians achieve salvation and to ensure that all things were done within the church 'in an understandable, fine and orderly way for edification'. Examples of such ordinances included the examination and installation of ministers, the performance of pastoral duties, the exercise of Christian discipline, the administration of the sacraments and the proper conduct of public worship and other religious ceremonies. Bucer asserted that the reformation ordinance in no way taught that these apostolic ordinances should be eliminated. A quick perusal of the chapter headings would make clear that the Simple Consideration established many prescriptions, ordinances and practices in these areas in accordance with oral apostolic tradition. In fact, Bucer stated in an aside aimed at his opponents, the reformation ordinance was only enforcing true apostolic tradition in its provisions that priests were to live blamelessly and to devote themselves to pastoral care rather than to secular concerns or to the singing or reading of masses, by specifying that the Bible be read and preached on during worship, and by requiring that services be conducted in a language understood by the congregation. ${ }^{23}$

It was necessary, however, to distinguish between those ordinances that edified the body of Christ and those that had become rank superstition because people believed they imparted forgiveness or divine grace. Bucer maintained that any consideration of apostolic tradition had to consider the number and nature of traditions accepted as apostolic by the church. There was no single book that listed all of those traditions recognized by the Fathers. Instead, a whole host of traditions of varying importance was scattered through the corpus of patristic writings. The Fathers recognized some traditions as binding (notwendig), whether they concerned doctrine, such as the canon of Scripture or the authority of the creeds, or of practice, such as the confession of faith and renunciation of the world and the devil at baptism. Other traditions, such as making the sign of the cross on the forehead of the baptized or feeding them milk and honey after baptism, were less important. The judgment as to which traditions were truly apostolic and necessary was based on Scripture

22. Bestendige Verantwortung, $1 \mathrm{r}-3 \mathrm{r}$.

23. Bestendige Verantwortung, $3 \mathrm{r}-7 \mathrm{r}$. and the testimony of the Holy Spirit. Because the writings of the Fathers did not always agree, they could not be used to argue for the necessity of apostolic tradition unless they themselves agreed with Scripture. ${ }^{24}$

Finally, Bucer took on the patristic citations that Gropper had used to attack the reformation ordinance. He began this section by stating a general principle: 'the holy Fathers were Christian teachers and had high gifts, and without doubt they oppose none of the chief and necessary doctrines or practices of our holy religion contained in the book of the Reformation in any way, if you do not try to distort or bend their writings against what the holy fathers themselves believed and practiced'.

Bucer followed up this indirect accusation of misrepresentation by readily agreeing with Gropper's first point raised in the Confutation that some of the church's doctrines and practices were indeed derived from the oral teachings of the apostles. This was, however, a non-issue: the Simple Consideration accepted this and in fact tried to restore these practices to their 'right and pious use'. The genuine controversy was not over whether oral apostolic tradition had any validity, but rather over which doctrines and practices had been given to the church by the apostles, and which of these were of equal authority with Scripture.

Bucer's approach to the passage from St. Basil was to question Gropper's interpretation by pushing it to its logical extreme:

Basil includes among the doctrines and practices that the church has received orally and not in writing... (the practice of) triple immersion in water at baptism, standing during congregational prayer on the Sundays during the seven weeks between Easter and Pentecost, and the words of invocation used when exhibiting the bread of thanksgiving and the cup of blessing. Do our opponents say that Basil wants to grant these customs and practices the same power for salvation as baptism, prayer, and the words and deeds of the Lord in the Lord's Supper which are given to us in Scripture? Will they say that Basil damns all those who do not hold to these practices in the same way as those who harm the most necessary part of the Holy Gospel ${ }^{25}$

If they did maintain this extreme view, Bucer argued, his opponents were only condemning themselves, since in Cologne babies were not immersed three times in water, people knelt rather than stood in prayer on the Sundays between Easter and Pentecost, and they did not use any invocation at all when exhibiting the bread and wine during the Mass.

24. Bestendige Verantwortung, $7 \mathrm{r}-10 \mathrm{r}$.

25 . Bestendige Verantwortung, $10 \mathrm{v}$. 
Bucer was willing to admit that some of the practices described by Basil-such as the confession of faith at baptism or the inclusion of congregational prayer and Scripture reading in the communion liturgy-were indeed necessary. However, 'every Christian could recognize' that these practices contributed more to furthering piety than did the previously mentioned practices. This argument became Bucer's basis for judging the authority of the Fathers regarding the traditions of the church. If a practice could not be eliminated without injury to Christian piety, it should be diligently observed, and indeed the Book of the Reformation did not eliminate any of these practices. However, those 'external signs and symbolic practices' which were not based on Scripture and did not truly serve piety were not of the same importance, nor could Basil's words about the authority of tradition be understood to apply to them. ${ }^{26}$

Having dealt at length with the interpretation of Basil, Bucer then turned to the remaining Fathers cited by Gropper. Rather than taking on each citation individually, he dealt with these citations as a group, arguing that it was important to consider the historical context in which they were written. The Fathers who emphasized apostolic tradition-Irenaeus, Tertullian and Augustine-were all writing against Manichaeans, Marcionites and other heretics who rejected portions of Scripture. They therefore had to rely on another source of authority in addition to Scripture. This did not mean, however, that any of the Fathers did not derive their own arguments from Scripture; in fact, they always sought confirmation of their teachings in Scripture. ${ }^{27}$

Bucer closed the discussion by reminding his readers that they were very distant from the time of the early church. Even Augustine had complained about the 'human presumptions' that had crept into the church in his day, and, as Bucer added, 'these have immeasurably increased since then'. Only Scripture could allow us to judge the value of oral tradition, and therefore the reformation ordinance was justified in requiring that all doctrine and practice be drawn from it. Finally, Bucer apologized for the length of his response. It was, however, necessary because his opponents deceived many good people by citing the 'old, valued traditions, doctrines and practices of the church' in their criticisms of the doctrines and practices prescribed in the reformation ordinance. ${ }^{28}$

Although (as is clear from this last remark) Bucer by no means refrained from criticizing his opponents, much of his discussion of the relationship between Scripture and apostolic tradition is surprisingly moderate by sixteenth

26. Bestendige Verantwortung, 10r-11r.

27. Bestendige Verantwortung, $11 \mathrm{v}-12 \mathrm{v}$.

28. Bestendige Verantwortung, $12 \mathrm{v}-14 \mathrm{r}$. century standards. It has, for instance, a less hostile tone than does Bucer's summary of his preaching at Bonn. By this I do not mean to make any statements about the Steadfast Defense as a whole or about its other chapters, some of which are more clearly polemical. However, first impressions are important, and it is significant that Bucer began his work by assuming a reasoned and scholarly manner of presentation rather than by openly attacking his opponents.

In addition to presenting his own position in a fairly dispassionate way, Bucer made use of rhetorical questions to win the support of his readers: 'What other book is so sure as the Bible in matters of faith?' 'Why seek to add anything beyond Scripture?' 'How can it hinder Christians seeking a reformation of the church to require that all teachings be referred to Scripture?' ${ }^{29}$ By seeming to grant many of his opponents' arguments and assuming a tone of 'sweet reasonableness', as illustrated by these rhetorical questions, he skillfully downplayed the fundamental differences between himself and his Catholic opponents. They were finding disagreement where none existed, he asserted, and in fact they could not substantiate their claims that the Simple Consideration taught anything (let alone many things) that opposed the oral instructions or practices handed down from the apostles or that it eliminated any (let alone countless) such ordinances. ${ }^{30}$ Bucer's tactic of glossing over or remaining silent on contested issues was a familiar one, something he had long employed in works aimed at a Catholic audience. It was a strategy he had followed with some success in his Psalms commentary of 1529 and had used ten years later in his colloquy with Georg Witzel at Leipzig. ${ }^{31}$

More pointed was Bucer's claim that the reformation ordinance actually re-instituted practices of the early church which had either lapsed over the centuries or were ignored by the very same Catholic clergy who were the most vocal defenders of apostolic tradition. This was a tactic that Bucer had employed as early as 1534 in his Defensio, and which he would use with increasing frequency in his anti-Catholic polemics over the 1540 s in the wake of the failed religious colloquies. ${ }^{32}$ Bucer charged that the chief reason his opponents attacked the reformation ordinance was their fear that it would re-establish the 'right, true apostolic ordinances', thereby limiting their privileges

29. Bestendige Verantwortung, $2 \mathrm{r}, 3 \mathrm{r}, 13 \mathrm{v}$.

30. Bestendige Verantwortung, $6 \mathrm{r}$

31. Amy Nelson Burnett, The Yoke of Christ: Martin Bucer and Christian Discipline (Sixteenth Century Essays and Studies, 26; Kirksville, MO: Sixteenth Century Journal, 1994), pp. 40-44, 125-28.

32. See his dedicatory letter to the French Chancellor Antoine Duprat, BOL 5: 1-15; Burnett, Yoke of Christ, pp. 132-36, 1141-42. 
and infringing on their incomes and 'lordly way of life', even though the ordinance was so moderate that it allowed them to retain their benefices as long as they allowed Christ's kingdom to be established among their subordinates. ${ }^{33}$

Such charges obviously undermined the more winsome and persuasive tone Bucer tried to maintain throughout his discussion of apostolic tradition. And his polemical urges did get the better of him at a few points, as when he rejected the claim that the Fathers taught that one should seek confirmation of 'true apostolic doctrine and ordinances from any particular church, even those that were first founded by the apostles themselves'. One must seek God's gifts where they are, not where they once were:

Where thorns and thistles now grow, you cannot pick grapes and figs, even though you could obtain much good wine and good figs from those places at the time when they were once stocked with vines and fig trees... but where there is obvious perversion of godly teaching and the multiplication of all sorts of sins and vices, those who seek apostolic tradition in such places are trying to harvest grapes from thorns and figs from thistles. ${ }^{34}$

To turn to how Bucer regarded the writings and practices of the early church, it is striking that he acknowledged the existence of extra-scriptural apostolic tradition on the basis of Scripture itself. What Bucer granted with one hand, however, he immediately took away with the other. Because Scripture mentioned the unwritten teachings and ordinances of the apostles, those traditions must exist. Bucer was very careful, however, to use the adjective 'apostolic' when he discussed binding tradition. Although he did not state this in so many words, it is clearly implied that for a tradition to be accepted it must truly stem from the apostles, and such apostolic origin was very difficult to prove. And in every case the legitimacy of those traditions had to be confirmed by referring them back to Scripture: 'only by means of the apostolic writings can we actually recognize which are the true apostolic traditions or not, and which of these must necessarily be observed or not. ${ }^{35}$ Apostolic tradition, as contained in the writings of the church fathers, remained subordinate to Scripture. ${ }^{36}$

33. Bestendige Verantwortung, $7 \mathrm{r}$.

34. Bestendige Verantwortung, 12v. Bucer derived this extended metaphor from Lk. 6.44.

35. Bestendige Verantwortung, $13 \mathrm{v}$.

36. Bucer's position here is no different from that of other reformers described by Scott Hendrix, 'Deparentifying the Fathers: the Reformers and Patristic Authority', in L. Grane, A. Schindler and M. Wriedt (eds.), Auctoritas Patrum: Contributions on the Reception of the Church Fathers in the 15th and 16th Century (Mainz: Philipp von Zabern, 1993), pp. 55-68.
This subordination is evident in Bucer's unwillingness to introduce patristic texts that were not already part of the debate. Throughout the Steadfast Defense, Bucer followed the strategy of responding to those citations used by Gropper. He did not cite additional patristic sources to counter those put forward by Gropper or to support his own arguments. Scripture, not patristic citation or early church practice, remained the foundation for Bucer's argumentation. Again, Bucer's summary of his preaching in Bonn is instructive. On the one hand, he could challenge the clergy and university of Cologne, the city's council and all Christians to find anything in his teaching that contradicted 'divine Scripture, the canons, the holy old councils and the teachings of the holy fathers', and he vigorously asserted that all his preaching was 'Christian and given to us by the Lord himself and his dear apostles and held by the oldest holy churches'. ${ }^{37}$ Nevertheless, even the 'holy fathers completely submitted themselves to the doctrine and ordinances of divine scripture and did not believe or obey all other doctrines and opinions, no matter how learned and holy... unless they could be proven through God's scripture and scriptural reasons'. ${ }^{38}$

Bucer's emphasis on the apostolic nature of 'tradition' alerts us to the ambiguity inherent in that term. While Bucer emphasized tradition (singular) as that which has been passed down from the apostles, Gropper took a broader view of traditions (plural) by implicitly identifying them with the myriad practices and ceremonies that had indeed been altered or eliminated by the reformation ordinance. ${ }^{39}$ Because they defined 'tradition' differently, they could each maintain diametrically opposed assertions about whether the Reformation ordinance was guilty of innovation. To some extent Gropper blurred this distinction by confining himself almost exclusively to the teachings and example of the early church, leaving the reader with the impression that the traditions he defended were all of patristic origin. ${ }^{40}$ At a few points in the Confutation, however, he was forced to cite later sources as, for instance, the decree of the Fourth Lateran Council requiring the yearly confession of all mortal sins to a priest. ${ }^{41}$ It was precisely at this point that Bucer could-and indeed

37. BDS 9/1, pp. 68.36-69.7.

38. BDS 9/1, pp. 38.36-39.4

39. John M. Headley, 'The Reformation as Crisis in the Understanding of Tradition', Archiv für Reformationsgeschichte 78 (1987), pp. 5-23.

40. In his 1538 Enchiridion, Gropper followed the same pattern of supporting his positions with a combination of Scripture and patristic citations, with very few scholastic sources cited; see Walter Lipgens, Kardinal Johannes Gropper 1503-1559 und die Anfänge der katholischen Reform in Deutschland (Münster: Aschendorff, 1951), pp. 71-73.

41. Gegenberichtung, 119r 
did - argue that his opponents were the true innovators by requiring a practice that the church fathers knew nothing about. ${ }^{42}$

Bucer was certainly not unique in his view that the evangelical church was closer to the ideals and practices of the early church than was the Roman church. ${ }^{43}$ What makes Bucer's arguments in the Steadfast Defense significant, however, is that Gropper's method of argumentation placed the burden of proof squarely on Bucer. To uphold his assertion that the Cologne reformation ordinance did not introduce innovations, Bucer had to respond directly and specifically to the patristic citations used by Gropper. As his discussion of patristic authority shows, Bucer chose to do so by emphasizing the patristic roots of public ceremonies that guided religious expression. This is completely in character with the practical bent of his ecclesiology and his concern for creating institutional structures that shaped Christian behavior. ${ }^{44}$ In his later works Bucer repeatedly described the ministries of the church as Word, sacraments and discipline - the latter being a very broad term that included not only oversight of individual conduct, whether clerical or lay, but also acts of public and private devotion and the proper ordering of public worship and other ecclesiastical ceremonies. ${ }^{45}$ Scriptural references to oral apostolic teaching, Bucer maintained, dealt with serious matters such as these, and not with trivial things like holy water, candles, vestments and the like. ${ }^{46}$ By the 1540s Bucer was convinced that the church needed well-established institutional structures, and he justified them in the same way that he justified in-

42. This is the core of Bucer's defense of the elimination of mandatory auricular confession; see Bestendige Verantwortung, $214 \mathrm{v}-221 \mathrm{r}$.

43. To cite one of the best known examples of how this argument was used, Calvin made the same claim in his letter to Francis I which prefaced his Institutes of the Christian Religion (trans. Ford Lewis Battles; Library of Christian Classics, 20; Philadelphia: Fortress Press, 1960), 1, pp. 18-23. Ian Hazlett has recently pointed out Bucer's influence on Calvin's letter, seen in a comparison of the former's dedicatory epistle of his 1534 Defensio adversa Axioma Catholicum and Calvin's letter to the French king; BOL 5, xxxiv. Melanchthon also held a similar position with regard to the continuity between the early church and the evangelical church; Peter Fraenkel, Testimonia Patrum: The Function of the Patristic Argument in the Theology of Philip Melanchthon (Geneva: Droz, 1961), pp. 170-78.

44. I have been unable to look at Donald W. Tyler Carr, 'The Influence of Patristic Writings on the Ecclesiology of Martin Bucer' (PhD dissertation, Southern Baptist Theological Seminary, 1981).

45. See, for example, his discussion in his 1543 catechism (BDS 6/3, pp. 243-63), and his lectures de vi et usu sacri ministerii given at Cambridge shortly before his death and published in Martin Buceri Scripta Anglicana fere omnia (Basel: Perna, 1577), especially pp. 570-86.

46. Bestendige Verantwortung, 3v. Bucer was here responding to Gropper's citation of St Paul in 1 Cor. 11.2 and 2 Thess, 2.15 . fant baptism - that is, by deriving them from Scripture and early church practices that accorded with Scripture. The form of these ceremonies or practices might vary, but their existence was necessary.

In his magisterial work on Bucer's ecclesiology, Gottfried Hammann has pointed to the fundamental ambivalence in Bucer's view of the church Fathers. On the one hand, Bucer could view the early church as normative, particularly on issues of doctrine. On the other hand, he could also consider the early church to be exemplary but not binding, particularly with regard to church practice. ${ }^{47}$ In the Steadfast Defense, however, Bucer makes the distinction between those practices which were binding on the church and those that were left voluntary. Perhaps rather than calling these practices exemplary, it is more accurate to call them secondarily normative-necessary for the church if they met the two criteria of being grounded in Scripture and of serving to edify the body of Christ or to establish order in the congregation.

This brings us to a final question. Are Bucer's statements on patristic authority in his Steadfast Defense, along with his practical proposals for the reform of the Cologne church, truly representative of his convictions? Cornelis Augustijn has observed that in his reform proposals advanced at Regensburg, Bucer endorsed practices that had long been eliminated in Strasbourg. ${ }^{48}$ The same could be said about the Cologne Reformation ordinance. In defending the ordinance against Gropper's attacks, Bucer could conceivably be arguing for practices he did not fully agree with.

There are two related answers to this question. First, the Cologne ordinance, like the reform proposals that stemmed from the religious colloquies, reflects Bucer's willingness to accept what was realistically possible, although less than ideal, rather than fighting tier what was ideal but therefore impossible. ${ }^{49}$ For this reason it is important to understand how Bucer defended these concessions to the audience of 'good-hearted' Christians both within and outside the archiepiscopal territory for whom the Steadfast Defense was intended.

47. Gottfried Hammann, Entre la secte et la cité: le projet d'Église du Réformateur Martin Bucer (Geneva: Labor et Fides, 1984), pp. 414-16; see also his earlier discussion of Bucer's views on the relationship between Scripture and tradition, pp. 119-30.

48. Cornelis Augustijn, 'The Quest of Reformation: The Diet of Regensburg 1541 as a Turning-Point', in H. Guggisberg and G. Krodel (eds.), Die Reformation in Deutschland und Europe: Interpretationen und Debatten, Archiv für Refomationsgeschiechte Sonderband (Gütersloh, Gütersloher Verlagshaus, 1993), pp. 64-80.

49. Wilhelm Neuser, 'Bucers programm einer "guten, leidlichen reformation" (1539-1541)', in Horizons Européens, pp. 227-39. 
On a more fundamental level, Bucer's Steadfast Defense is only one piece of a much larger puzzle. It can certainly be said that Bucer's use of the church Fathers in Cologne was a more precise and detailed version of the concord proposals he had advocated as early as 1534. But the larger question regarding the role of the church Fathers in Bucer's later works can only be answered by a deeper analysis of the Cologne Reformation, of Bucer's use of the Fathers more generally in his debates and polemical exchanges with Catholics over the 1540s, and of his final works in England. And that must be the goal of a future study. 